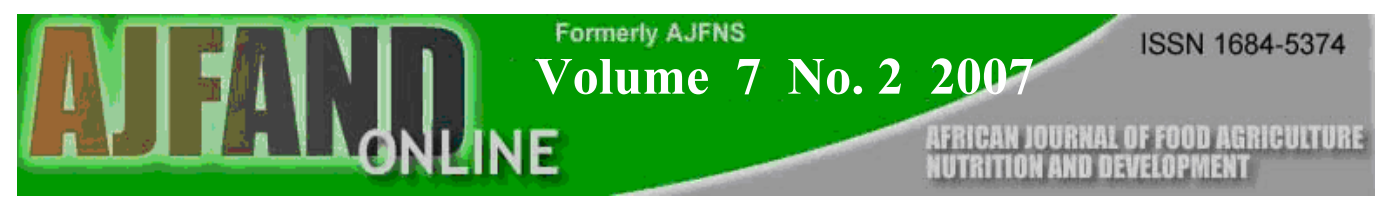

\title{
NUTRITIONAL STATUS OF MAIZE FERMENTED MEAL BY FORTIFICATION WITH BAMBARA-NUT
}

\section{By}

Theodore I. Mbata*1 ${ }^{1}$, M.J. Ikenebomeh ${ }^{2}$, I. Ahonkhai ${ }^{3}$

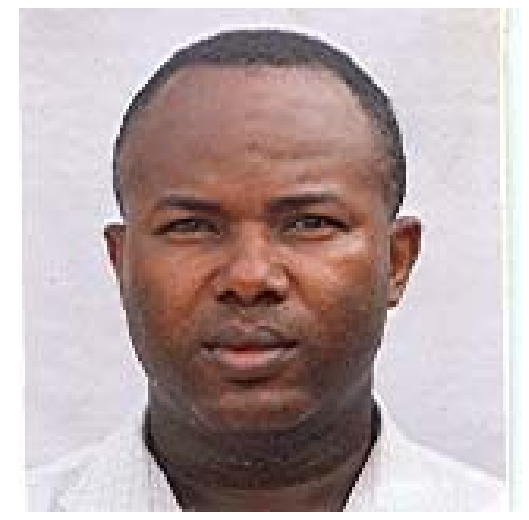

Theodore I. Mbata

\section{Corresponding author.}

${ }^{* 1}$ Department of Applied Microbiology and Brewing. Nnamdi Azikiwe University, Awka, Nigeria. Tel: +2348032618922. E-mail: theoiyke@yahoo.com.

${ }^{2}$ Department of Microbiology, University of Benin, Benin City, Nigeria.

${ }^{3}$ Department of Pharmaceutical Microbiology, University of Benin, Benin city, Nigeria.

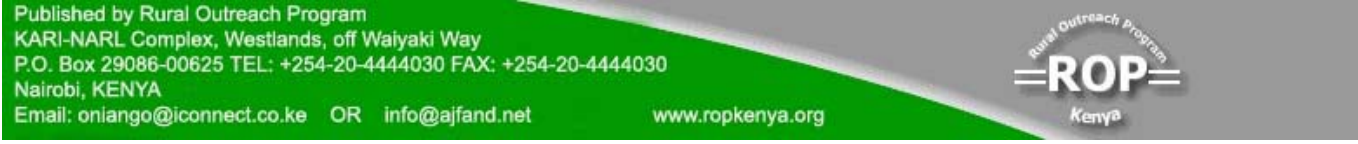




\section{ABSTRACT}

Studies were conducted to develop an appropriate household/small scale enterprise level technique for the production of bambara-nut-fortified fermented maize dough or meal by comparing different treatments, processing methods and fortification levels. The effect of fortification of maize based traditional foods with legume protein, bambara-nut at $0 \% .10 \%$ and $20 \%$ replacement levels, on the rate of fermentation and organoleptic product quality were investigated. Sensory characteristics, amino acid pattern, proximate composition (moisture, protein, fat, ash, carbohydrate) $\mathrm{pH}$, titratable acidity and rheological properties (pasting temperature, peak viscosity, viscosity at $95^{\circ} \mathrm{C}$ and $95^{\circ} \mathrm{C}$ hold and viscosity at $50^{\circ} \mathrm{C}$ ) were used as the indices of quality.

The results obtained showed that Bambara-nut addition caused only minimal changes in the proximate composition with the exception of protein content, which increased remarkably from $10.1 \%$ to $16.4 \%$ and $10.1 \%$ to $16.2 \%$ with $20 \%$ bambara-nut addition respectively for boiled and raw bambara-nut fortified fermented maize dough. The product $\mathrm{pH}$ decreased with concomitant increase in moisture, fat, ash and titratable acidity with increasing bambara-nut addition. A significant improvement was also achieved in the lysine and tryptophan pattern of the fortified dough compared to the unfortified lot. However, boiling bambara-nut for 20 min before incorporation into the maize for milling and fermentation imparted a desirable flavour.

This results showed that the most appropriate technique for the production of bambara- fortified high protein fermented maize dough has been suggested to involve incorporation of boiled whole bambara-nut in soaked maize before milling and fermentation for improved sensory characteristics, enhanced nutritive value and optimal functional properties. Little or no changes in the pasting viscosity characteristics occurred in raw bambara-nut fortified fermented maize dough. Organoleptic evaluation revealed that the foods were well accepted. Based on the findings of the study, the application of Bambara-nut fortification to traditional foods suggests a viable option of promoting the nutritional quality of African maize - based traditional foods with acceptable rheological and cooking qualities.

Keywords: Fermented maize meal, bambara-nut fortification, protein quality ,rheology 


\section{INTRODUCTION}

Maize processing in West Africa is based on traditional indigenous technology, which utilizes local raw materials, and in most cases, local equipment. These technologies are simple, with most of them having been developed through experience in the production of products of desirable quality. Common unit operation have been described in previous studies $[1-6]$

Maize is processed into a wide range of foods and beverages ranging from weaning and children's break fast porridge to adult main meals and snack foods $[2,5]$ : Traditional foods are formulated based on local staple usually cereal grains, such as maize, sorghum, millet and rice, roots and tubers such as, yam, cassava etc [7]. To be suitable for the feeding of young children, the cereals are prepared in liquid form by diluting with a large quantity of water, thereby resulting in a large volume with low energy and nutrient density $[8,9]$.

Many brands of low - cost proprietary weaning foods have been developed from locally available high calorie cereals and legumes in tropical Africa [7, 8, 10-13]. This has been suggested by the integrated child development scheme (ICDS) and FAO to combat malnutrition among mothers and children of low socio-economic groups. Evidence indicates that it is quite possible to improve the nutrient quality and acceptability of these cereals and legumes and exploit their potentials as human foods by adopting newer scientific processing methods [14].

In Nigeria and other parts of West Africa, cereal grains lack two essential amino acid, lysine and tryptophan [15-17], thus making their protein quality poorer compared to that of animals [18].

Germination of fermentation has been reported as ways of improving cereal-protein quality [19]. Previous study has documented increased lysine and tryptophan in germinated corn [20], improved vitamin content in germinated soghum and maize [21], increased amino acid and vitamins in fermented blends of cereals and soybeans [8].

Despite the reported improvement in the nutrient status of germinated and fermented cereal based diets in sub-Saharan Africa, the nutrient needs of infants and sick adults are still not being met.

Earlier studies have documented the need for fortification of traditional fermented maize porridge with legume [22-24]. Despite the various reports, information on the effect of bambara-nut fortification on the nutritive value of some maize based traditional foods is scarce. Based on these facts, the study was undertaken to formulate and improve the quality and nutritive value of maize fermented meal by fortification with bambara-nut.

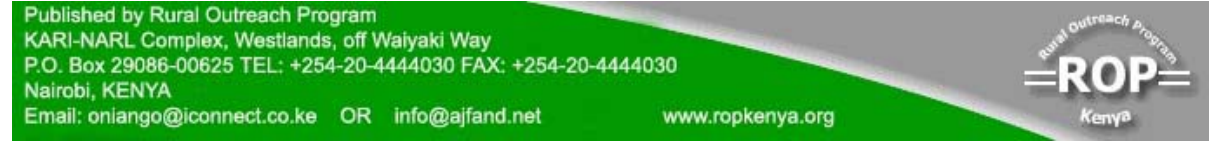




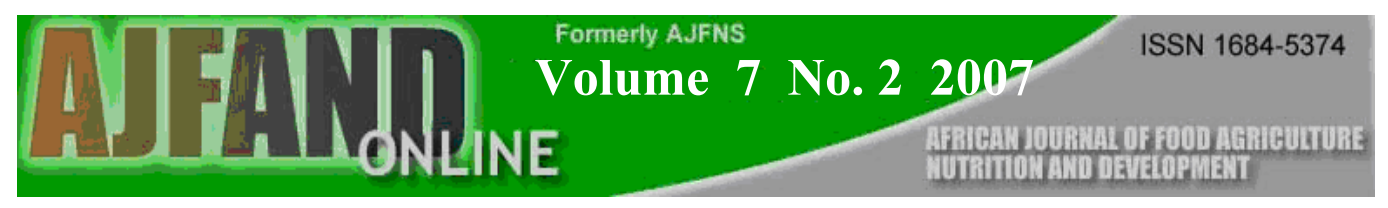

\section{METHODS}

Maize (Zea mays L) and Bambara-nut (Vigna subterranean L) were purchased from Ota farms in Ogun state and Eke Awka market in Anambra State, respectively all in Nigeria and used for the study. They were all transported to the laboratory in clean polyethylene bags for later use.

\section{Preparation of Bambara-nut-fortified weaning foods.}

Maize dough was prepared using the traditional method of cleaning, washing and steeping in water for $24 \mathrm{~h}$ : Soak (in water for $1 \mathrm{~h}$ ) in one stage and boiled ( $20 \mathrm{~min}$ ) in another stage to dehulled bambara-nut and add separately to the maize at $10 \%$ and $20 \%$ concentration. The maize-bambara-nut blend milled using a disc attrition mill (Hunt No. 2A premier mill, Hunt and Co, UK ), mixed into a dough with water (3:1 meal: water - ratio) and allowed to ferment spontaneously at ambient temperature $\left(30^{\circ} \mathrm{C}\right)$ for one day.

\section{Preparation of traditional unfortified fermented maize dough.}

This was prepared by soaking clean selected maize grains in water for $24 \mathrm{~h}$, washing and milling to an average particle size of less than $3 \mathrm{~mm}$. The meal was mixed with water and kneaded into a smooth dough of about $50 \%$ moisture content. The dough samples were allowed to ferment spontaneously at ambient temperature $\left(30^{\circ} \mathrm{C}\right)$ for three day. 

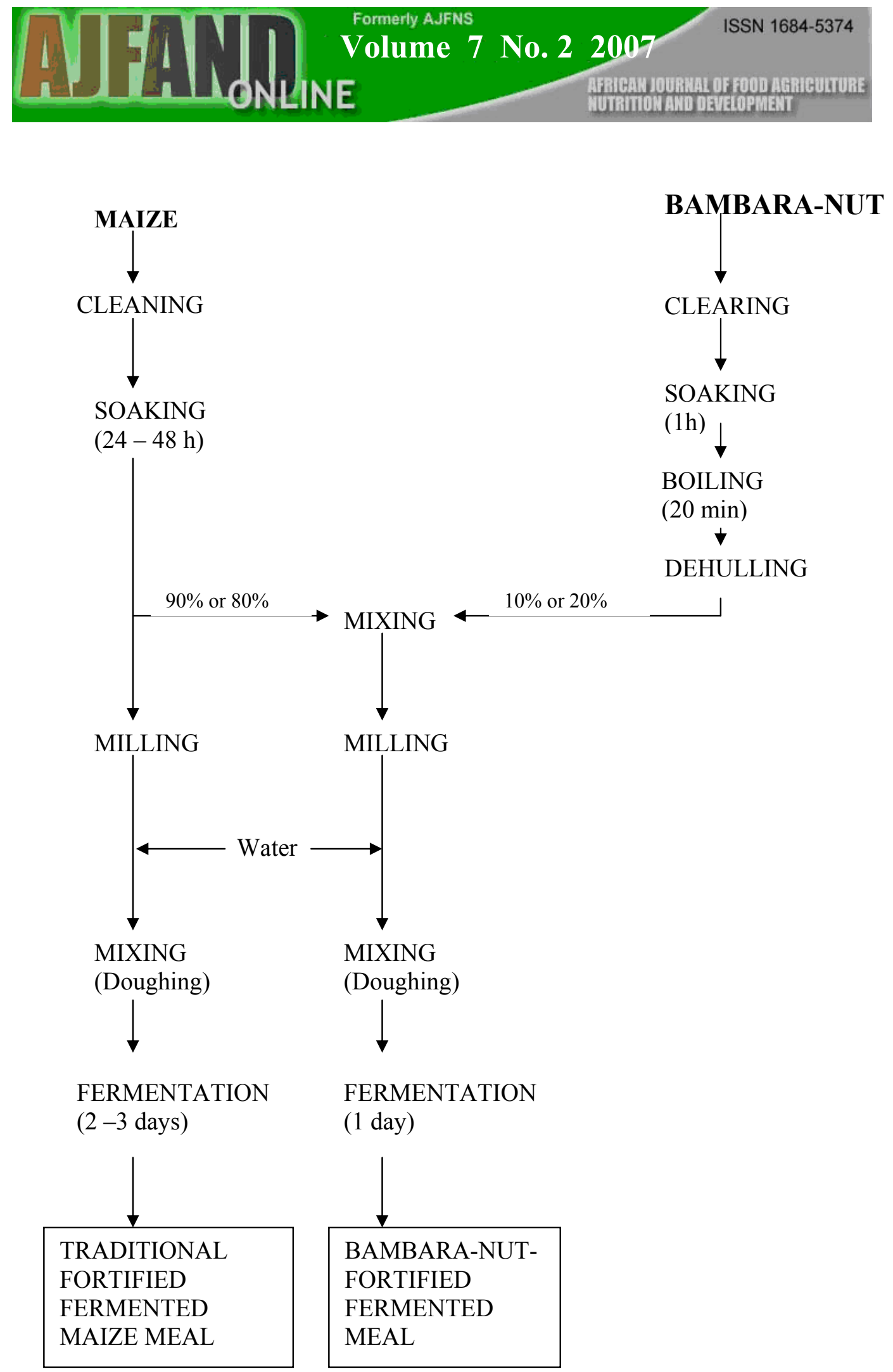

Fig 1: Flow diagram for the production of bambara-nut-fortified and unfortified fermented maize meal samples.

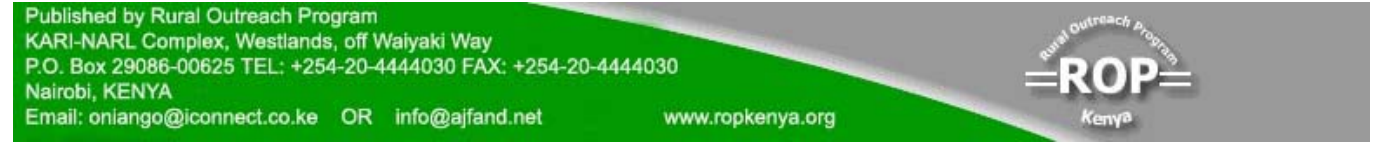




\section{Fermentation studies}

Samples of dough were taken during fermentation and analysed for titratable acidity and $\mathrm{pH}$, to determine the effect of processing method and level of fortification on the fermentation characteristic.

\section{pH and Titratable acidity}

Ten grams of sample was mixed in $100 \mathrm{ml}$ of $\mathrm{Co}_{2}$ - free distilled water. The mixture was allowed to stand for $15 \mathrm{~min}$, shaken at $5 \mathrm{~min}$ interval and filtered with Whatman No. 14 filter paper. The $\mathrm{pH}$ of the filterate was measured using a $\mathrm{pH}$ meter (Model HM-305, Tokyo, Japan). Ten millilitres aliquots (triplicates) were pipetted and titrated against $\mathrm{O} .1 \mathrm{M} \mathrm{NaOH}$ to phenolphthalein end-point and the acidity was calculated as g lactic acid/100.

\section{Viscosity measurement}

The cooked paste viscosity of the slurries were determined with a brabender viscoamylograph (Brabender, Duisburg Germany) equipped with a $700 \mathrm{~cm}-\mathrm{g}$ sensitivity cartridge. A $10 \%$ slurry (dry matter basis) of each flour was prepared with $500 \mathrm{ml}$ distilled water and the slurry was heated uniformly from $25^{\circ} \mathrm{C}$ at a rate of $1.5^{\circ} \mathrm{C}$ per min to $95^{\circ} \mathrm{C}$ and held for $15 \mathrm{~min}$, and cooled at the same rate to $50^{\circ} \mathrm{C}$. The brabender viscoamylograph rheological indices (gelatinization temperature, peak viscosity, viscosity at $95^{\circ} \mathrm{C}$ and $95^{\circ} \mathrm{C}$ hold, viscosity on cooling to $50^{\circ} \mathrm{C}$, the index of gelatinization, and starch stability) were determined from obtained values.

\section{Proximate composition}

Samples of the fermented doughs were analyzed by standard procedures [25] for moisture, protein, fat, ash.and carbohydrate.

\section{Amino acid analysis}

Lysine concentration in the sample was determined in triplicates, by digestion under vacuum with $6 \mathrm{M} \mathrm{HCl}$ in sealed ampules at $110^{\circ} \mathrm{C}$ for $22 \mathrm{~h}$. The hydrolysates were derivatized and analyzed for amino-acids on a water HPLC system controlled by Millenium 2010 software (Water DIV, Millipore Corp, Milford, MA, USA) Tryptophan was determined according to the AOAC [26] method.

\section{Sensory Evaluation}

Sensory characteristics of the fortified fermented maize dough products were assessed by 10 trained members of the Department Applied Biochemistry and Food Technology, Nnamdi Azikiwe University, Awka Nigeria. Fresh samples of cooked porridge prepared with each of the products by boiling a $10 \%(\mathrm{w} / \mathrm{v})$ slurry of the dough for $15 \mathrm{~min}$ were assessed for their colour, texture, flavour (aroma), taste and overall acceptability. The judges were instructed to sip water before and after assessing each product. The judges recorded sensory characteristics of each sample using 8 -point hedonic scale, where:

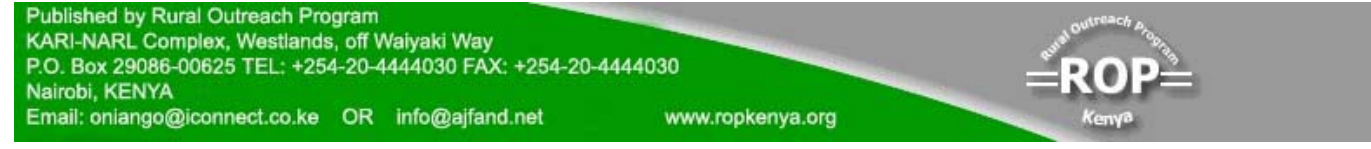




$\begin{array}{lll}8 & = & \text { like extremely } \\ 7 & = & \text { like very much } \\ 6 & = & \text { like moderately } \\ 5 & = & \text { like slightly } \\ 4 & = & \text { dislike slightly } \\ 3 & = & \text { dislike moderately } \\ 2 & = & \text { dislike very much and } \\ 1 & = & \text { dislike extremely }\end{array}$

Each treatment was evaluated three times by each panelist.

\section{Statistical analysis}

The data were subjected to analysis of variance in a completely randomized design using the method of Snedecor and Cochran [27]. Significance difference was accepted at $\mathrm{p} \leq 0.05$ level.

\section{RESULTS}

The effect of bambara-nut treatment, fortification and rate of fermentation of traditional maize dough are shown in Table 1. The addition of raw bambara-nut or heat treatment of the dough accelerated acid production. The steeping of maize grains generally encouraged higher lactic acid production by the prevailing microorganism. The rate of acid production increased with increase in the level of fortification. The boiled bambara-nut blend with the maize resulted in greater titratable acidity than in raw bambara-nut blend to the maize meal before fermentation during the different periods of fermentation. The $\mathrm{pH}$ of the formulated food decreased as fermentation lasted.

Table 2 showed the proximate ash, crude protein, total fat, moisture and carbohydrate of unfortified and fortified dough. The bambara fortified maize meal had higher values of ash, crude protein, total fat, moisture and carbohydrate than in the unfortified maize meal.

Table 3 showed the brabender amylograph pasting viscosities of fermented maize dough fortified with bambara-nut before milling and fermentation. The addition of raw bambara-nut to maize before milling and fermentation had relatively minimal effect on the hot paste viscosity characteristics of traditional fermented maize dough.

Table 4 showed the amount of available lysine and tryptophan after fortification. The result showed that bambara-nut contained lysine in concentration that can contribute significantly to improving the amino acid pattern of the blend before milling and fermentation. The overall acceptability scores of the various sensory attributes are shown in Table 5. 


\section{DISCUSSION}

The $\mathrm{pH}$ of the formulated weaning foods decreased from 6.4 to 3.5 , while the titratable acidity increased from 2.6 to $10.6 \mathrm{mg} \mathrm{NaOH} / \mathrm{g}$ sample in both raw and boiled bambara nut. The $\mathrm{pH}$ of the unfortified products also decreased from 6.5 to 3.6 and titratable acidity increased from 1.3 to $6.5 \mathrm{mg} \mathrm{NaOH} / \mathrm{g}$ sample with $0 \%$ bambara-nut addition. The acidic nature of the product could be due to the production of lactic acid produced by microorganism associated with maize dough fermentation. It has also been reported that microorganisms involved in fermentation affect the nutritional level of fermented food [28]. In this study, bambara-nut fortification increased the acid production. This was also probably due to availability of more nutrients for microbial proliferation and enhanced metabolic activities. This early production of carboxylic acid and the consequent rise in titratable acidity, is important to avoid proliferation of undesirable organisms resulting in poor fermentation

The proximate fat and ash increased, with increased level of Bambara-nut fortification. It is also clear from the result that all the fortified foods were nutritious, since the products provided one third of the Recommended Dietary Allowance (RDA) with respect to protein (10 to $12 \%$ ) as recommended by World Health Organization [29] and National Institute of Nutrition [30] for children and rural mothers. The proximate characteristic of all fortified foods were within the range reported for weaning and supplementary food [29].

The brabender viscoamylograph as presented in Table 3 showed useful information on the hot and cold paste viscosity of starch based food. The values obtained for gelatinization temperature viscosity at $95^{\circ} \mathrm{C}$, peak viscocity and viscosity at $50^{\circ} \mathrm{C}$, were similar for traditional unfortified maize dough and samples of dough fortified with raw bambara-nut especially at $10 \%$ replacement level. Starch stability was slightly reduced in the bambara-nut fortified samples, indicating a slightly greater breakdown of the paste during cooking. Little or no viscosity changes were therefore expected when raw bambara-nuts were incorporated in soaked maize before milling and fermentation to obtain a bambara-fortified product. On the contrary, fortification of maize with boiled bambara-nut before milling and fermentation reduced peak viscosity (from 310 to $250 \mathrm{BU}$, in the case of $20 \%$ fortification) and viscosity at $95^{\circ} \mathrm{C}$. Starch stability, however was improved with increase in level of fortification.

All the blends produced from fermented raw and boiled bambara-nut-maize dough were found to display desirable starch stability and consistent gelling tendency. However, only the blend boiled bambara-nut-maize dough was within acceptable limits as observed by similar workers [10]. This blend could be used as a low-cooked viscosity weaning food, which could potentially increase the food intake of the child. The others due to its high gelatinization index could be recommended only as food for adults

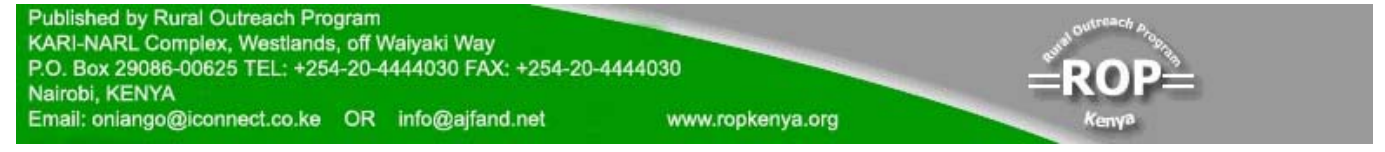


There was progressive increase in the lysine and tryptophan content in the fortified maize dough. Lysine and tryptophan are essential amino acids which are vital for growth and maintenance of the body, are often limiting in some cereals. [15, 17] .The incorporation of bambara-nut to maize dough increased these amino-acids content.

From the present study, bambara-nut fortification improved the protein quality, by elevating the levels of some essential amino acids, which are limiting in the unfortified maize meal.

The organoleptic evaluation showed that, although different combinations of cereals/maize and legumes/bambara-nut, were used to prepare the food mixtures, all the supplements were liked by the trained panelists. This shows that although there were slight variations in taste, flavour and overall acceptability, all the fortified foods were liked very much. None of the panelists developed any side effects like diarrhea and emesis after the sensory evaluation.

\section{CONCLUSION}

The fortified foods prepared with bambara-nut and maize was nutritious and conformed to specifications as recommended by National Institute of Nutrition and Food and Agriculture Organization (FAO) to combat malnutrition especially in low socio-economic groups. It has special importance for use in weaning foods, catch-up growth and may improve birth weights.

\section{ACKNOWLEDGEMENT}

The authors are grateful for the technical assistance of staff of Nigerian Institute of Forestry Research (NIFOR) Benin City, Nigeria. 
Table 1: Effect of bambara-nut treatment and fortification method on the rate of fermentation of traditional maize dough.

\begin{tabular}{|l|l|l|l|l|l|l|l|l|}
\hline \multirow{2}{*}{$\begin{array}{l}\text { Bambara-nut fortification } \\
\text { (level and Treatment) }\end{array}$} & \multicolumn{4}{|c|}{ pH } & \multicolumn{3}{c|}{$\begin{array}{l}\text { Titratable acidity } \\
\text { mg NaOH/g sample }\end{array}$} \\
\cline { 2 - 10 } & $0 \mathrm{~h}$ & $24 \mathrm{~h}$ & $48 \mathrm{~h}$ & $72 \mathrm{~h}$ & $0 \mathrm{~h}$ & $24 \mathrm{~h}$ & $48 \mathrm{~h}$ & $72 \mathrm{~h}$ \\
\hline $\begin{array}{l}\text { Control Traditional dough } \\
(0 \% \text { Bambara-nut) }\end{array}$ & $6.55^{\mathrm{a}}$ & $4.5^{\mathrm{ab}}$ & $4.0^{\mathrm{a}}$ & $3.6^{\mathrm{c}}$ & $1.3^{\mathrm{d}}$ & $5.3^{\mathrm{c}}$ & $6.2^{\mathrm{c}}$ & $6.5^{\mathrm{e}}$ \\
\hline $\begin{array}{l}\text { Fortification } \\
\text { fermentation }\end{array}$ & & & & & & & & \\
\hline $10 \%$ raw bambara-nut & $6.30^{\mathrm{a}}$ & $4.25^{\mathrm{a}}$ & $3.90^{\mathrm{a}}$ & $3.60^{\mathrm{c}}$ & $2.6^{\mathrm{c}}$ & $7.1^{\mathrm{b}}$ & $80^{\mathrm{b}}$ & $8.6^{\mathrm{c}}$ \\
\hline $20 \%$ raw bambara-nut & $6.42^{\mathrm{a}}$ & $4.01^{\mathrm{b}}$ & $3.80^{\mathrm{a}}$ & $3.62^{\mathrm{c}}$ & $2.8^{\mathrm{c}}$ & $7.5^{\mathrm{b}}$ & $7.9^{\mathrm{b}}$ & $9.7^{\mathrm{b}}$ \\
\hline $10 \%$ boiled bambara-nut & $5.50^{\mathrm{b}}$ & $4.01^{\mathrm{b}}$ & $3.70^{\mathrm{a}}$ & $3.50^{\mathrm{c}}$ & $4.2^{\mathrm{b}}$ & $7.5^{\mathrm{b}}$ & $8.2^{\mathrm{b}}$ & $9.8^{\mathrm{b}}$ \\
\hline $20 \%$ boiled bambara-nut & $5.40^{\mathrm{b}}$ & $3.90^{\mathrm{b}}$ & $3.75^{\mathrm{a}}$ & $3.62^{\mathrm{c}}$ & $5.0^{\mathrm{a}}$ & $8.0^{\mathrm{a}}$ & $8.4^{\mathrm{b}}$ & $10.6^{\mathrm{a}}$ \\
\hline
\end{tabular}

${ }^{1}$ Titratable acidity values are means of triplicate determinations expressed on day weight basis. Mean values in the same column with different superscripts differ significantly $(p<0.05)$. Stated values are means of triplicate trails

Table 2. Proximate composition of weaning food formulations of fermented maize dough samples fortife with bambara - nut using different methd and treatment ${ }^{1}$.

\begin{tabular}{|l|c|c|c|c|c|}
\hline $\begin{array}{l}\text { Bambara-nut } \\
\text { fortification (level } \\
\text { and treatment) }\end{array}$ & $\begin{array}{c}\text { Moisture } \\
(\%)\end{array}$ & $\begin{array}{c}\text { Protein } \\
\mathbf{( \% )}\end{array}$ & Fat (\%) & $\begin{array}{c}\text { Ash } \\
(\%)\end{array}$ & $\begin{array}{c}\text { Carbohydrate } \\
(\%)\end{array}$ \\
\hline $\begin{array}{l}\text { Control Traditional } \\
\text { dough }(0 \% \text { bambara- } \\
\text { nut) }\end{array}$ & $50.2 \pm 1.3^{\mathrm{b}}$ & $10.1 \pm 0.4^{\mathrm{c}}$ & $4.0 \pm 0.3^{\mathrm{c}}$ & $1.0 \pm 0.1^{\mathrm{c}}$ & $70.4 \pm 0.2^{\mathrm{c}}$ \\
\hline $\begin{array}{l}\text { Fortification before } \\
\text { fermentation }\end{array}$ & & & & & \\
\hline $10 \%$ raw Bambara-nut & $50.6 \pm 0.7^{\mathrm{b}}$ & $12.5 \pm 0.3^{\mathrm{b}}$ & $5.1 \pm 2^{\mathrm{b}}$ & $1.5 \pm 0.2^{\mathrm{b}}$ & $72.6 \pm 0.2^{\mathrm{b}}$ \\
\hline $20 \%$ raw Bambara-nut & $51.9 \pm 1.0^{\mathrm{ab}}$ & $16.2 \pm 1.0^{\mathrm{a}}$ & $6.3 \pm 0.7^{\mathrm{a}}$ & $2.4 \pm 0.1^{\mathrm{a}}$ & $73.9 \pm 0.1^{\mathrm{a}}$ \\
\hline $\begin{array}{l}10 \% \text { boiled Bambara- } \\
\text { nut }\end{array}$ & $52.7 \pm 1.1^{\mathrm{a}}$ & $12.6 \pm 0.7^{\mathrm{b}}$ & $5.1 \pm 0.5^{\mathrm{b}}$ & $1.5 \pm 0.1^{\mathrm{b}}$ & $71.1 \pm 0.1^{\mathrm{ab}}$ \\
\hline $\begin{array}{l}20 \% \text { boiled Bambara- } \\
\text { nut }\end{array}$ & $52.9 \pm 0.5^{\mathrm{a}}$ & $16.4 \pm 1.1^{\mathrm{a}}$ & $6.5 \pm 0.5^{\mathrm{a}}$ & $2.4 \pm 0.3^{\mathrm{a}}$ & $71.4 \pm 0.5^{\mathrm{ab}}$ \\
\hline
\end{tabular}

${ }^{1}$ Values are means \pm SD of three independent determination, expressed on dry weight basis except for moisture.

Mean values in the same column with different superscripts differ significantly $(\mathrm{p}<0.05)$

Table 3: Brabender amylograph pasting viscosities of fermented maize dough samples fortified with Bambara-nut before milling and fermentation.

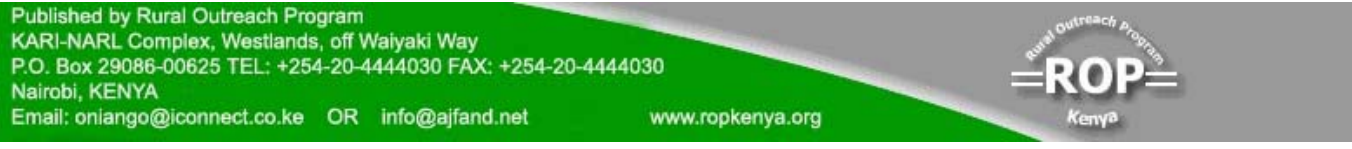




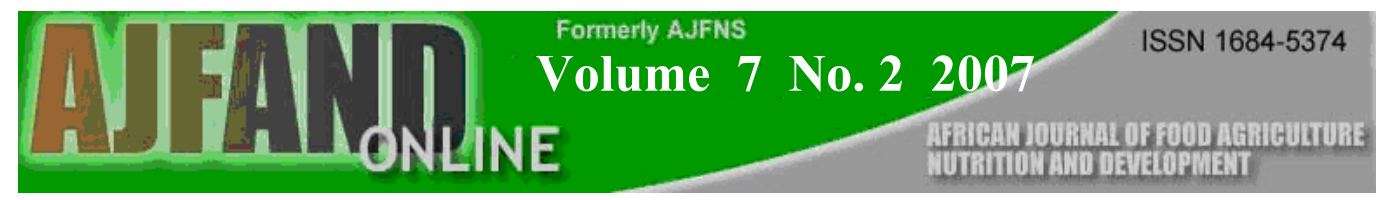

\begin{tabular}{|l|l|l|l|l|l|}
\hline $\begin{array}{l}\text { Pasting } \\
\text { characteristics }\end{array}$ & $\begin{array}{l}\text { Traditional } \\
\text { unfortified } \\
\text { maize dough }\end{array}$ & \multicolumn{2}{|l|}{$\begin{array}{l}\text { Ratio of boiled whole } \\
\text { bambara-nut added }\end{array}$} & \multicolumn{2}{|l|}{$\begin{array}{l}\text { Ratio of raw whole } \\
\text { bambara-nut added }\end{array}$} \\
\cline { 3 - 6 } & $\mathbf{1 0 \%}$ & $\mathbf{2 0 \%}$ & $\mathbf{1 0 \%}$ & $\mathbf{2 0 \%}$ \\
\hline $\begin{array}{l}\text { Gelatinization } \\
\text { Temp. }\left({ }^{\circ} \mathrm{C}\right)\end{array}$ & $80.1 \pm 0.7^{\mathrm{a}}$ & $73.2 \pm 0.8^{\mathrm{c}}$ & $73.8 \pm 0.5^{\mathrm{b}}$ & $76.0 \pm 0.8^{\mathrm{a}}$ & $73.2 \pm 0.6^{\mathrm{c}}$ \\
\hline $\begin{array}{l}\text { Peak Viscosity } \\
\text { (BU) }\end{array}$ & $320 \pm 5^{\mathrm{b}}$ & $300 \pm 5^{\mathrm{c}}$ & $250 \pm 10^{\mathrm{d}}$ & $380 \pm 5^{\mathrm{a}}$ & $350 \pm 5^{\mathrm{b}}$ \\
\hline $\begin{array}{l}\text { Viscosity at } \\
95^{\circ} \mathrm{C}(\mathrm{BU})\end{array}$ & $310 \pm 10^{\mathrm{a}}$ & $300 \pm 10^{\mathrm{b}}$ & $250 \pm 5^{\mathrm{c}}$ & $350 \pm 20^{\mathrm{a}}$ & $325 \pm 5^{\mathrm{a}}$ \\
\hline $\begin{array}{l}\text { Viscosity after } \\
15 \text { min at 95 } \mathrm{C}\end{array}$ & $280 \pm 5^{\mathrm{a}}$ & $300 \pm 5^{\mathrm{b}}$ & $235 \pm 0^{\mathrm{c}}$ & $290 \pm 10^{\mathrm{a}}$ & $300 \pm 0^{\mathrm{a}}$ \\
\hline $\begin{array}{l}\text { Starch stability } \\
\text { (BU) }\end{array}$ & $40 \pm 7^{\mathrm{bc}}$ & $0 \pm 7^{\mathrm{c}}$ & $15 \pm 5^{\mathrm{d}}$ & $90 \pm 11^{\mathrm{a}}$ & $50 \pm 5^{\mathrm{b}}$ \\
\hline $\begin{array}{l}\text { Viscosity on } \\
\text { cooling to 50 } \\
\text { (BU) }\end{array}$ & $440 \pm 10^{\mathrm{a}}$ & $370 \pm 10^{\mathrm{c}}$ & $320 \pm 5^{\mathrm{d}}$ & $430 \pm 15^{\mathrm{a}}$ & $410 \pm 10^{\mathrm{b}}$ \\
\hline $\begin{array}{l}\text { Index of } \\
\text { gelatinization }\end{array}$ & 160 & 70 & 85 & 140 & 110 \\
\hline
\end{tabular}

Values are means of three replicates of \pm SD. Means within a row with different superscripts are significantly different $(\mathrm{p}<0.05)$

Table 4: Amino acid content (g/16gN) of fortified food made with Bambara-nut.

\begin{tabular}{|l|l|l|}
\hline \multicolumn{2}{|l|}{ Traditional unfortified Maize dough } & Fortified maize \\
\hline Lysine & $0.5 \pm 0.11^{\mathrm{d}}$ & $4.20 \pm 0.21^{\mathrm{c}}$ \\
\hline Tryptophan & $0.1 \pm 0.08^{\mathrm{c}}$ & $0.86 \pm 0.06^{\mathrm{b}}$ \\
\hline
\end{tabular}

Values are means of three replicates \pm standard deviation

Table 5.Organoleptic characteristics and acceptability of fortified maize dough from bambara-nut.

\begin{tabular}{|l|l|l|l|l|l|}
\hline & \multicolumn{5}{|c|}{ Means scores } \\
\hline Supplement & Color & Texture & Flavor & Taste & Overall \\
\hline 1 & 6.8 & 6.8 & 6.8 & 7.0 & 6.9 \\
\hline 2 & 6.6 & 7.0 & 7.0 & 6.8 & 6.9 \\
\hline 3 & 6.3 & 6.1 & 6.6 & 7.0 & 6.5 \\
\hline 4 & 6.5 & 6.1 & 6.1 & 6.4 & 6.3 \\
\hline 5 & 6.5 & 6.3 & 6.0 & 6.3 & 6.3 \\
\hline 6 & 6.3 & 6.0 & 5.5 & 6.1 & 6.0 \\
\hline 7 & 6.2 & 6.1 & 6.3 & 6.3 & 6.3 \\
\hline 8 & 6.3 & 6.0 & 6.1 & 5.5 & 6.0 \\
\hline
\end{tabular}

${ }^{\mathrm{a}}$ Means are scores of 10 Judges and not significantly $(\mathrm{p}>0.05)$ different between supplementary foods.

${ }^{\mathrm{b}}$ Panelists used 8 point hedonic scale: 


\section{REFERENCES}

1. Christian WFK. Fermented food of Ghana. FR.I Project Report Food Research Institute, Accra, Ghana 1967.

2. Dovio FE. Maize: Its processing and preparation for food in Ghana. Special Report: Food Research Institute, Accra, Ghana 1968.

3. Akinrele IA. Fermentation studies on Maize during the preparation of a traditional Africa starch-cake Food. J Sci Food Agric 1970; 21: 619 - 625.

4. Bediaka-Amaoah B and HG Muller. Studies on Kenkey with particular reference to calcium and phytic acid. Cereal Chem. 1976. 53:355-375.

5. Plahar WA and HK Leung. Composition of Ghana fermented maize meal and the effect of soy fortification on sensory properties J. Sci food Agric 1983. 34:407 - 411 .

6. Sefa - Dedeh S and EO Mensah Traditional food processing technology and high proteins food production. Food and Nutr. Bull 1991. 13: 43 - 49.

7. Akpapunam MA and S Sefa-Dedeh. Traditional lactic acid fermentation, malt addition and quality development in maize-cowpea weaning blends. Food and Nutr. Bull 1995. 16: 75 - 80.

8. Onilude AA, Sanni AI and MI Ighalo. Effect of process Improvement on the physico-chemical properties of infant weaning food from fermented composite blends of cereal and soybeans. Plant Foods Hum Nutr 1999. 54:239 - 250.

9. Chopra JG. Food practices among Trinidadian Children. J. Am Diet Assoc. 1966; 49 (6): $497-501$.

10. Livingstone AS, Feng JJ and GN Malleshi Development and nutritional quality evaluation of weaning foods based on malted, popped and roller dried wheat and chicken. Int. J. Food Sci. Technol. 1993; 28:35 - 43.

11. Baskaran V, Mahadevamma, Malleshi NG, Shankara R and BR Lokesh. Acceptability of supplementary foods based on popped cereals and legumes suitable for rural mothers and children. Plant Foods Hum Nutr 1999; 53: 237 247.

12. Mahgoub SEO. Production and evaluation of weaning foods based on sorghum and legumes. Plant Foods Hum Nutr. 1999; 54:29-42. 
13. Sanni AI; Asiedu M and GS Ayernor Influence of processing conditions on the nutritive value of Ogi-baba, a Nigerian fermented sorghum gruel. Plant Foods Hum Nutr. 2001; 56: 217 - 223.

14. Malleshi NG and HSR Desikachar Formulation weaning food with low hot paste viscosity based on malted ragi and green gram flour. J. Food Sci. 1982; 19: 193 - 197.

15. FAO/WHO/UNU, Expert consultation Energy and protein requirements. WHO Technical Report Series, No 721, Geneva 1985.

16. Chavan JK and SS Kadam. Nutritional improvement of cereals by Fermentation CRC Crit Rev. Food Sci. Nutr 1989. 28: 349 - 400.

17. Hoshiai K. Current world supplies of and requirement for essential amino acid. Food Nutr. Bull 1991; $29-39$.

18. Horn PJ and HM Schwartz. Kaffir Corn malting and brewing studies: Amino Composition of Kaffir corn grain and malt. J Food Sci. 1961. 40:65.

19. Lorri W. Nutritional and Microbiological evaluation of fermented cereal weaning Foods $\mathrm{PhD}$ thesis, Chalmers University of Technology, Gotenborg, Sweden 1993.unpublished data .

20. Tsai CY, Dalby A and RA Jones. Lysine and tryptophan increases during germination of maize seed. Cereal Chem. 1975; 52: $356-360$.

21. Asiedu M, Lied E, Nilsen R and K Sandnes. Effect of Processing (sprouting and/or fermentation on sorghum and maize II: vitamins and amino acid composition. Biological evaluation of maize protein. Food Chem. 1993; 48: $201-204$.

22. Marero LM, Paymne EM, Aquanaldo AR and S Homono. Technology of weaning food formulation prepared from germinated cereals and legumes. $J$. Food Sci. 1988; 23:1391 - 1395.

23. Gahlawat $\mathbf{P}$ and S Sehgal. Protein quality of weaning Foods based on locally available cereal and pulse combination. Plant Foods Hum Nutr. 1994. 46: 245 $-253$.

24. Nti CA and WA Plahar. Chemical and biological characteristics of a West African weaning Food supplemented with cowpea (Vigna unguiculata) Plant Foods Hum Nutr 1995. 48: 45 - 54.

25. AOAC. Official Methods of Analysis $16^{\text {th }}$ edn. Arlington, VA: Association of Official Analytical Chemists. 1998; vol 1 and 2. 


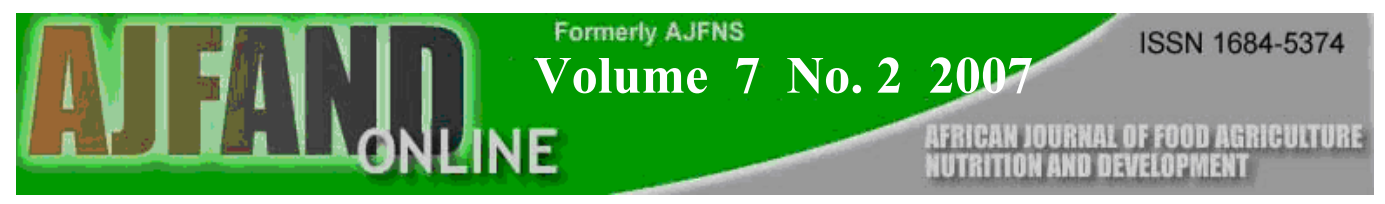

26. AOAC. Official Methods of Analysis. 15th edn. Arlington, VA: Association of Official Analytical Chemists. 1990; 725.

27. Snedecor GW and WG Cochran. A statistical method. lowa State University Press, Ames, Iowa, USA. 1967.

28. Newman RK and DC Sands. Nutritional value of corn fermented with Lysine excreting Lactobacilli. Nutr. Rep. Int. 1984; 30: 1287 - 1293.

29. FAO/WHO/UNU. Expert consultation. Energy and Protein requirements. WHO Technical Report Series, 1985; 724:113 - 130.

30. National Institute of Nutrition Acceptability trials of ready-to-eat foods in rural ICDs centers. In: Annual Report, National Institute of Nutrition. 1992; 1 -13 . 